\title{
Perceived Effectiveness of Sales Promotion Techniques amongst South African Generation Y Students
}

\author{
Heleneze-Tiane Marais \\ North West University (Vaal Triangle Campus) \\ Email: helenezemarais@yahoo.com \\ Natasha de Klerk PhD. \\ North West University (Vaal Triangle Campus) \\ Email: Natasha.deKlerk@nwu.ac.za \\ Ayesha Lian Bevan-Dye PhD. \\ North West University (Vaal Triangle Campus) \\ Email: Ayesha.Bevandye@nwu.ac.za
}

\section{Doi:10.5901/mjss.2014.v5n21p51}

Abstract

The increasing competition and the predicted changes in the retail sector are pressurising marketers to be more competitive in order to ensure that their brands are amongst the leading brands on the market. Marketers constantly need to develop innovative marketing strategies to create brand awareness, as well as to stimulate demand for specific brands. An important tool in this regard is the marketing communication mix, of which sales promotion is one of the most effective elements in the fast moving consumer goods (FMCG) sector. It is the responsibility of marketers to select the most appropriate sales promotion technique for a specific market segment or, more specifically, to select the most appropriate technique to effectively encourage the desired effect on the consumer buying behaviour. The South African Generation Y cohort (individuals born between 1986 and 2005) accounts for 38 percent of the total South African population. The African portion of this cohort (hereafter referred to as African Generation Y represented 83 percent of the total South African Generation Y cohort in 2013, making this a very attractive market segment. Marketers in the FMCG sector seeking to target this lucrative segment would need to understand their preferred sales promotion techniques. Therefore, this study sought to determine which sales promotion techniques (coupons, discounts, free samples, bonus packs) were perceived as being the most effective in encouraging brand loyalty, brand switching, purchase acceleration, stockpiling and product trial in the FMCG sector amongst the African Generation $Y$ cohort in South Africa. A quantitative study, following the descriptive research design, was undertaken, whereby a structured self-administered questionnaire was used to gather the required data. A convenience sample of 600 African Generation $Y$ students across two South African public registered higher education institutions' campuses situated in the Gauteng province was taken. The collected data were analysed using descriptive statistics and a one-sample t-test. The findings suggest that in South Africa, African Generation Y students have positive attitudes towards different sales promotion techniques and that these techniques are suitable for inducing specific consumer buying behaviours concerning low involvement products. Furthermore, the findings indicate that the buy one get one free and free sample offers are the most preferred sales promotion techniques and are more likely to exert an influence on this cohort's buying behaviours than the other sales promotion techniques.

Keywords: Sales promotion; low involvement products; consumer buying behaviour

\section{Introduction}

The South African retail sphere offers attractive growth opportunities, which suggests that major changes in this sector are imminent. National retail companies such as Pick 'n Pay, Shoprite and Spar are aiming to expand over the next few years by increasing their number of retail outlets in South Africa. Added to this, the arrival of international retail companies, such as Wal-Mart, is putting further pressure on the level of competition in South Africa's retail market (RMB Private Bank, 2011). The fast moving consumer goods (FMCG) industry is a major industry worldwide (Bala \& Kumar, 2011). Internationally and nationally, it is identified as the product category that utilises the majority of retailers' shelf space and accounts for a substantial percentage of their turnover (Pillay, 2007). FMCGs, also known as low involvement 
products (LIPs) (Hamlin \& Wilson, 2004), are consumer products that are used on a daily basis and include household cleaning products, toiletries (for example, toothpaste) and groceries (for example, bread and milk). These products are relatively inexpensive and purchased frequently (Leahy, 2011) and, as such, involve routinised consumer purchase behaviour (Perreault \& McCarthy, 2006), which requires minimal information because the consumer purchases such products on a routine basis (Schiffman \& Kanuk, 2010).

The increasing competition and the predicted changes in the retail sector are pressurising marketers to be more competitive in order to ensure that their brands are amongst the leading brands on the market. Marketers constantly need to develop innovative marketing strategies to create brand awareness, as well as to stimulate demand for specific brands. An important tool in this regard is the marketing communication mix, of which sales promotion is one of the most effective elements in the FMCG sector. It is the responsibility of marketers to select the most appropriate sales promotion technique for a specific market segment or, more specifically, to select the most appropriate technique to effectively encourage the desired effect on the consumer buying behaviour.

The South African Generation Y cohort (individuals born between 1986 and 2005) (Markert, 2004) accounts for 38 percent of the total South African population. The African portion of this cohort (hereafter referred to as African Generation Y), make up the vast majority of the country's Generation Y cohort, standing at approximately 83 percent in 2013 (Statistics South Africa, 2013). Marketers are likely to be particularly interested in African Generation Y university graduates given that a tertiary education is associated with a higher future earning potential and a higher social status in a society, translating into them acting as opinion leaders amongst the wider South African Generation Y cohort (BevanDye, Dhurup \& Surujlal, 2009). Marketers in the FMCG sector seeking to target this lucrative segment would need to understand their preferred sales promotion techniques.

As such, the primary aim of the study reported on in this article was to determine which sales promotion techniques (coupons, discounts, free samples, bonus packs) were perceived as being the most effective in encouraging brand loyalty, brand switching, purchase acceleration, stockpiling, and product trial, amongst the African Generation Y cohort in South Africa.

\section{Literature Review}

\subsection{Sales promotion}

Marketing communication is a crucial tool in any organisation's strategic marketing efforts, and may include the use of advertising, public relations and publicity, personal selling, sales promotion, and direct and interactive marketing, or a combination thereof (Kotler, 2003). Whilst the specific objectives of a marketing communication strategy may differ, they generally involve informing, persuading and reminding a target audience about the organisation's market offerings (Ferrel \& Hartline, 2008) in order to build awareness of and demand for that organisation's market offerings (Schiffman, Kanuk \& Wisenblit, 2010).

Sales promotion expenditure typically accounts for the majority of the marketing communication budget for FMCG organisations (Ferrel \& Hartline, 2008; Belch \& Belch, 2012). Whilst sales promotion may be trade- or consumer-oriented (Belch \& Belch, 2012), this study focused only on consumer-oriented sales promotion, which involves offering a variety of short-term incentives to end consumers in order to encourage the trial or purchase of a market offering (Kotler, 2003). According to the Promotional Products Association International (2004), sales promotion is a highly effective marketing communication technique in that it has a recall rate of 76 percent compared to television advertisements with a recall rate of 54 percent. Belch and Belch (2012) indicate that because of factors such as increased consumer deal proneness, declining brand loyalty and the growing power of major retail chains, many FMCGs organisations are shifting a significant amount of their promotional spending from advertising to sales promotion activities,

As sales promotion starts making up a larger portion of the marketing communication budget, so marketers face the challenge of selecting the most appropriate sales promotion technique(s) to target particular market segments (Kotler, 2003; Belch \& Belch, 2012). While different sales promotion techniques are focused on the same primary objective of increasing sales by inducing purchasing, each technique is unique and is set to achieve specific objectives such as to induce trial, encourage repeat purchase, increase consumption of existing brand, encourage switching from other brands, and the like (Belch \& Belch, 2012). In addition, sales promotion techniques may be used to defend current customers, who may view the sales promotion as a reward for supporting the brand (Gardener \& Trivedi, 1998). Regardless of the specific objectives, sales promotion is ultimately a marketer's effort to exert an influence on the buyer's reaction in order to achieve the desired response from the consumer (Gilbert \& Jackaria, 2002; Ndubisi \& Moi, 2006; Gamliel \& Herstein, 2011). 


\subsection{Sales promotion techniques}

The variety of sales promotion methods that may be employed are limited only by the creativity of the organisation offering the promotion (Ferrell \& Hartline, 2008). Well-known techniques include free samples, coupons, rebates, discounts (price-off deals), premiums, bonus packs, loyalty programmes, contests, sweepstakes and the like (Kotler, 2003; Ferrell \& Hartline, 2008; Belch \& Belch, 2012). Coupons, discounts, free samples and bonus packs are some of the most effective sales promotion techniques employed by marketers and retailers to increase short-term sales (Gamliel \& Herstein, 2011).

A coupon is a certificate with a stated value, presented to the retail store for a price reduction on a specific item (Arens, Weigold \& Arens, 2011), which is granted immediately at the time of purchase (Lamb, Hair \& McDaniel, 2009). Coupons are presented to consumers by direct mail, on the product's packaging, through the media, direct mail, door-todoor leaflets and at the point of sale (Pickton \& Broderick, 2005). Semenik (2002) opine that by offering coupons marketers are providing a price sensitive consumer that takes the time and effort to cut out coupons with a discount, while the product is selling at full price to the regular customer. Reasons for using coupons include rewarding loyal customers, encouraging current customers to buy greater quantities, attracting customers that have been lost to competing brands (Pride \& Ferrell, 2010), inducing the trial of new, improved or modified products amongst current and non-users (Belch \& Belch, 2012), encouraging repurchasing and encouraging brand switching by competitors' customers (Semenik, 2002).

A discount is a short term price reduction of the regular price of a product (Belch \& Belch, 2012) and has several synonyms, namely price-off vouchers (Shimp, 2010), money-off vouchers (Pickton \& Broderick, 2005), cents-off vouchers (Semenik, 2002) and price incentives (Du Plessis, Cook, Van Heerden, Van Rooyen, Mulder, Du Plessis, Franck \& Muir, 2010). Discounts are appealing to consumers because they provide an immediate reward (Shimp, 2010) and an easily recognised value to the consumer (Belch \& Belch, 2012). The use of the discount sales-promotion technique offers marketers and retailers several benefits. A discount promotion require minimal testing and can be implemented in a short time period (Yeshin, 2006), it can be controlled by the marketer (Semenik, 2002), thereby ensuring that the discount will reach the intended target market and it can assist in manufacturers gaining greater trade support from the retailer (Belch \& Belch, 2012). Furthermore, discounts can stimulate sales (Pride \& Ferrell, 2010), encourage consumers to repurchase or to purchase greater volumes (Shimp, 2010), encourage consumers to switch brands and can persuade price sensitive consumers to buy (Lamb et al., 2009). However, discounts may attract only current and not new customers (Belch \& Belch, 2012) and if continuously offered, may result in a weak brand image as customers may always expect lower prices and may perceive the brand as low cost or low quality (Pride \& Ferrell, 2010). Furthermore, discounts are relatively easy to copy, which may result in price wars among competitors (Pickton \& Broderick, 2005), and often result in consumers delaying purchasing until a discount is offered (Yeshin, 2006).

A free sample is a trial-size version of a product that is given to the consumer at no extra cost (Belch \& Belch, 2012) in order to encourage product trial; for example, a small container of body lotion included when purchasing a magazine (Pickton \& Broderick, 2005). Sampling offers credibility, as the consumer can experience the benefits of the product first hand (Ouwersloot \& Duncan, 2008). Consumers generally perceive a certain amount of risk in trying new products, and samples help mitigate that risk in that they allow the consumer to try the product prior to purchase (Lamb, Hair, McDaniel, Boshoff, Terblanche, Elliott \& Klopper, 2010). Samples can be distributed through direct mail, door-todoor delivery, on the package of another product, in retail stores or through the media (Bird, Blem, Duckles, Koekemoer, Skinner \& Van der Westuizen, 1998). Sampling is beneficial in restoring a declining product and demonstrating a product that is difficult to describe in words alone (Du Plessis et al., 2010). Sampling is especially effective when the consumer perceives the product to be different from that of competitors (Ouwersloot \& Duncan, 2008), or to encourage competitors' customers to switch brands (Lamb et al., 2009). Furthermore, sampling can stimulate sales when a product is still in the early stage of the product life cycle (Pride \& Ferrell, 2010) or establish a brand within an area with weak market share (Semenik, 2002).

Premiums, such as buy-one-get-one-free (hereafter referred to as BOGOF) or bonus packs (Yeshin, 2006), are defined as a sales promotion technique offering items, either free or at a small cost, as an incentive for consumers to purchase a product (Pride \& Ferrell, 2010). Premiums can include more of the product (multiple units) offered at the regular price, such as BOGOF, also referred to as 'two-for-the-price-of-one' (Lamb et al., 2010) packages that include more of the product (Du Plessis et al., 2010), or a bonus pack with a different product (Yeshin, 2006). In the literature, BOGOF is identified as one of the most frequently used premiums (Pickton \& Broderick, 2005; Lamb et al., 2009; Shimp, 2010). Premiums are used to entice consumers to buy immediately (Belch \& Belch, 2012), reinforce the consumer's purchase decision, induce trial for new or improved products, increase consumption, encourage repeat purchase (Shimp, 2010) and persuade consumers to switch brands (Lamb et al., 2010). As an added advantage, offering premiums can 
discourage the current customers to switch to brands (Pickton \& Broderick, 2005; Arens et al., 2011; Belch \& Belch, 2012).

\subsection{Effect of sales promotion techniques on consumer buying behaviour}

Whilst consumers' overall attitude towards sales promotion techniques is positive (Osman, Fah \& Foon, 2011), the different sales promotion techniques have different effects on consumer buying behaviour (Shi, Cheung \& Prendergast, 2005), that may include brand switching, purchase acceleration, stockpiling, product trial and brand loyalty (Gilbert \& Jackaria, 2002). Moreover, it is possible for one sales promotion technique to affect the consumer's buying behaviour in more than one way. Different types of sales promotion techniques cause different responses from different consumers, and this is frequently because of the individual characteristics of each consumer (Shi, Cheung \& Prendergast, 2005).

Brand switching is the extent to which a consumer can be persuaded to purchase a brand other than their usual brand (Mittal \& Sethi, 2011). Shukla (2009) believes that brand switching is an impulsive occurrence where consumers often aim to save money, which then results in them switching brands. Therefore, when retailers implement a low price strategy, it encourages consumers to switch brands. Brand loyal consumers will purchase the regular brand resulting in long-term sustainability, whereas consumers who are not brand loyal are prepared to test various brands and switch between them. Evidence from the literature indicates that BOGOF promotions are regarded as an effective technique for encouraging brand switching (Gilbert \& Jakaria, 2002; Mittal \& Sethi, 2011).

Purchase acceleration is the extent to which a consumer can be encouraged to purchase a product earlier than planned or needed (Mittal \& Sethi, 2011). Kivetz, Urminsky and Zheng, (2006) indicate that purchase acceleration can be achieved either through motivating consumers to purchase the product more regularly or by motivating them to increase the number of products purchased. According to Percy (2008), promotions aimed at achieving repeat purchases, are often used to take consumers temporarily out of the market or to encourage purchase acceleration. Discounts (Gilbert \& Jackaria, 2002) and premiums (Mittal \& Sethi, 2011) are viewed to be successful in encouraging purchase acceleration amongst consumers.

Stockpiling refers to the extent to which a consumer can be enticed to purchase greater quantities of a product than are required (Mittal \& Sethi, 2011). As an added bonus to retailers, Dawes (2004) highlights that consumers tend to consume a stockpiled product faster because they have a surplus. Kristof (2012) believes that consumers are more likely to stockpile a specific product when the product is offered at a low price. Evidence from the literature indicates that BOGOF promotions (Gilbert \& Jackaria, 2002), as well as discounts and coupons (Mittal \& Sethi, 2011) are regarded as effective techniques for encouraging stockpiling.

Product trial involves a consumer purchasing a product that they have never previously used (Mittal \& Sethi, 2011). According to Ndubisi and Moi (2006), repeat purchase is an effective measurement for determining customer satisfaction and the success of the product trial. Evidence from the literature suggests that discounts (Gilbert \& Jackaria, 2002), premiums (Mittal \& Sethi, 2011) and sampling (Ndubisi \& Moi, 2006) are successful sales promotion techniques for encouraging product trial. According to the findings of a study conducted by Ndubisi and Moi (2006), coupons were the least effective in encouraging product trial, but sampling, discounts and premiums were successful. However, premiums are found in-store, which means that the promotion will not increase brand awareness before product trial.

Brand loyalty comprises two dimensions, namely the behavioural dimension, which relates consumers frequently and consistently purchasing the same brand within a product category, and the attitudinal dimension, which involves a consumer's commitment towards a particular brand (Schiffman et al., 2010). Brand loyalty results in positive word-ofmouth communication (Moraga, Parraga \& González, 2008) and makes current customers more resistant to competitors' offerings (Jensen \& Hansen, 2006). Belch and Belch (2012) suggest that loyalty programmes, discounts, BOGOF promotions and premiums aid in building brand loyalty.

\section{Methodology}

This study was quantitative in nature and followed a descriptive research design, utilising a single cross-sectional sample.

\subsection{Sample}

The target population relevant to this study was African Generation Y students, aged between 18-24 years, enrolled fulltime at South African registered public higher education institutions (HEIs) in 2012. The sampling frame comprised the 23 registered South African public HEls, as listed by Higher Education in South Africa (HESA, 2009). Using a judgement 
sampling method, this sampling frame was narrowed down to two HEl campuses located in the Gauteng Province, one belonging to a traditional university and the other to a university of technology. A non-probability convenience sample of 600 full-time undergraduate African Generation Y students was used to conduct this study. Lecturers at the two HEls were contacted and asked if they would allow the questionnaire to be distributed to their students either during class or after class.

\subsection{Measurement instrument and data collection procedures}

This study used a structured, self-administered questionnaire to gather the required data. In order to measure the extent to which African Generation Y students perceived sales promotion techniques as being effective in encouraging their LIP consumption-related behaviour, a scale developed and validated by Gilbert and Jackaria (2002) was used. Participants were requested to indicate the extent to which they agreed/disagreed with the effectiveness of the sales promotion techniques of coupons (five items), discounts (five items), free samples (five items) and BOGOF (five items) in encouraging their LIP consumption-related behaviours of brand switching, purchase acceleration, stockpiling, product trial and brand loyalty. Scaled responses were measured on a six-point Likert scale, ranging from strongly disagree (1) to strongly agree (6). In addition, the questionnaire included a section designed to gather the participants' demographical information and a cover letter outlining the purpose of the study.

In order to establish reliability, the questionnaire was piloted on a convenience sample of 43 students on a South African HEl campus that did not form part of the main sample. The results of this pilot test were considered in finalising the questionnaire. A Cronbach alpha value of 0.75 was computed for the entire scale, which is above the recommended level of 0.70 (Field, 2009). After permission was solicited by lecturers for distributing the questionnaire to their students, the questionnaire was distributed to those students during lectures. The students were informed that participation was strictly on a voluntary basis.

\section{Results}

\subsection{Sample characteristics}

Of the 600 questionnaires handed out, 543 questionnaires were returned completed. The majority of the participants indicated being 20 years of age, followed by those who indicated being 19 years of age and 21 years of age. The sample included a greater number of female than male participants. Concerning the participants monthly grocery expenses, the majority indicated spending between R501 and R1000 per month on groceries, followed by those who indicated spending less than R500 and those who spend between R1001 and R1500. The demographical information of the sample's participants is presented in Table 1.

Table 1. Sample description

\begin{tabular}{cccccccc}
\hline Gender & $\begin{array}{c}\text { Percent } \\
\mathbf{n}(\%)\end{array}$ & Institution & $\begin{array}{c}\text { Percent } \\
\mathbf{n}(\%)\end{array}$ & Age & $\begin{array}{c}\text { Percent } \\
\mathbf{n}(\%)\end{array}$ & Monthly grocery expenses & $\begin{array}{c}\text { Percent } \\
\mathbf{n}(\%)\end{array}$ \\
\hline Male & $207(38)$ & HEI A & $245(45)$ & 18 & $65(12)$ & Less than R500 & $130(24)$ \\
Female & $336(62)$ & HEI B & $298(55)$ & 19 & $116(22)$ & R501 - R1000 & $284(53)$ \\
& & & & 20 & $137(25)$ & R1001- R1500 & $74(14)$ \\
& & & & 21 & $104(19)$ & More than R1500 & $53(9)$ \\
& & & & 22 & $70(13)$ & Missing & $2(0.4)$ \\
& & & 23 & $29(5)$ & & \\
\hline
\end{tabular}

\subsection{Reliability and validity}

A Cronbach alpha value of 0.82 was computed for the attitudes towards sales promotion techniques scale in the main survey, which exceeds the suggested value of 0.70 . With regard to content validity, the scale scored a 0.186 average inter-item correlation value, which was within the recommended range of 0.15 to 0.50 (Clark \& Watson, 1995). This suggests that the items in the scale do measure the students' attitudes towards the different sales promotion techniques in relation to LIP buying behaviour. 


\subsection{Descriptive statistics}

Once the reliability and validity of the scale had been ascertained, the descriptive statistics were computed. Table 2 outlines the means and standard deviations (SD) pertaining to the extent to which African Generation Y students perceive the four types of sales promotion techniques for inducing the five types of consumption-related behaviour.

Table 2. Descriptive statistics

\begin{tabular}{lcccccccc} 
& \multicolumn{9}{c}{ Sales promotion technique } \\
\cline { 2 - 9 } & \multicolumn{2}{c}{ Coupon } & \multicolumn{2}{c}{ Discount } & \multicolumn{2}{c}{ Free sample } & \multicolumn{2}{c}{ BOGOF } \\
\hline Behaviour & Mean & SD & Mean & SD & Mean & SD & Mean & SD \\
\hline Brand switching & 3.61 & 1.51 & 4.27 & 1.38 & 4.60 & 1.44 & 4.71 & 1.42 \\
Purchase acceleration & 3.41 & 1.51 & 3.95 & 1.44 & 4.42 & 1.47 & 4.42 & 1.53 \\
Stockpiling & 3.77 & 1.54 & 4.25 & 1.42 & 4.51 & 1.38 & 4.69 & 1.42 \\
Product trial & 2.89 & 1.52 & 3.19 & 1.48 & 3.83 & 1.57 & 3.70 & 1.63 \\
Brand loyalty & 4.39 & 1.54 & 4.50 & 1.42 & 4.53 & 1.50 & 4.68 & 1.53 \\
\hline & 3.61 & 0.87 & 4.03 & 0.80 & 4.38 & 0.95 & 4.44 & 0.92 \\
\hline
\end{tabular}

The highest means across the LIP consumer-related behaviours were recorded for the sales promotion techniques of BOGOF (Mean = 4.44) and free samples (Mean = 4.38), suggesting that these two techniques are suitable for inducing brand switching, purchase acceleration, stockpiling, product trial and brand loyalty amongst African Generation $Y$ students in the South African market. The sales promotion technique of BOGOF (Mean $=4.71$ ) was indicated as the most appropriate way of inducing brand switching, whilst free samples (Mean $=4.42$ ) and BOGOF (Mean $=4.42$ ) were indicated as being equally likely to induce purchase acceleration. The BOGOF technique (mean $=4.69$ ) was also indicated as the most likely inducer of stockpiling. According to the results in Table 2, product trial is most likely to be induced by free samples (Mean $=3.83$ ) and BOGOF (Mean = 3.70). Similarly, BOGOF (Mean $=4.68$ ) and free samples (Mean $=4.53$ ) were indicated as the two sales promotion techniques likely to induce brand loyalty.

\subsection{One sample t-test}

In order to determine whether the perceived effectiveness of the different sales promotion techniques in encouraging LIP consumption-related behaviours was statistical significance, a one-sample t-test was computed. The significance level was set at the 5 percent level. Given that the interest was in the area of agree to agree strongly, the expected mean was set at 3.5 and only means above 3.5 were considered for inclusion in the analysis. As such, the perceived effectiveness of coupons on encouraging purchase acceleration (Mean $=3.41$ ) and product trial (Mean $=2.89$ ) were omitted from the analysis, as was the effectiveness of discounts on product trial (Mean $=3.19)$. Table 3 reports on the relevant t-statistics and p-values.

Table 3. One sample t-test

\begin{tabular}{lcccccccc} 
& \multicolumn{7}{c}{ Sales promotion technique } \\
\cline { 2 - 9 } & \multicolumn{2}{c}{ Coupon } & \multicolumn{2}{c}{ Discount } & Free sample & \multicolumn{2}{c}{ BOGOF } \\
\hline Behaviour & t-statistic & p-value & t-statistic & p-value & t-statistic & p-value & t-statistic & $p$-value \\
\hline Brand switching & 1.659 & 0.098 & 13.036 & $0.000^{*}$ & 17.850 & $0.000^{*}$ & 19.969 & $0.000^{*}$ \\
Purchase acceleration & - & - & 7.248 & $0.000^{*}$ & 14.572 & $0.000^{*}$ & 13.991 & $0.000^{*}$ \\
Stockpiling & 4.043 & $0.000^{*}$ & 12.332 & $0.000^{*}$ & 17.013 & $0.000^{*}$ & 19.410 & $0.000^{*}$ \\
Product trial & - & - & - & - & 4.870 & $0.000^{*}$ & 2.891 & $0.004^{*}$ \\
Brand loyalty & 13.528 & $0.000^{*}$ & 16.419 & $0.000^{*}$ & 15.940 & $0.000^{*}$ & 18.056 & $0.000^{*}$ \\
\hline \multicolumn{7}{c}{ * Significant at the 0.05 level } \\
\hline
\end{tabular}

As is evident from Table 3, while the perceived effect of coupons on encouraging stockpiling of and brand loyalty towards LIPs is statistically significant, their effect on brand switching is not. The perceived effect of discounts on encouraging brand switching, purchase acceleration, stockpiling and brand loyalty are all statistically significant. The free sample and BOGOF sales promotion techniques both have a statistically significant perceived effect on inducing brand switching, purchase acceleration, stockpiling, product trial and brand loyalty. 


\section{Discussion}

This study investigated African Generation $Y$ students' attitudes towards the perceived effectiveness of different sales promotion techniques in encouraging LIP consumption-related behaviours. The results of this study provide valuable insights into the Generation $Y$ students' preferred sales promotion techniques as well as the preferred techniques for inducing the specific behaviours of brand loyalty, brand switching, stockpiling and purchase acceleration. The findings of the study suggest that, in general, African Generation $Y$ students have a positive attitude towards the use of sales promotion techniques for LIPs. In terms of the perceived effectiveness of the sales promotion techniques across LIP consumption-related behaviours, BOGOF promotions scored highest, followed by free sampling and then discounts. Of all of the sales promotion techniques, coupons scored the lowest.

Whilst the sales promotion techniques of discounts, free samples and BOGOF are all suitable techniques to employ in encouraging LIP brand switching, BOGOF appears to be the most appropriate method, which is consistent with the findings of Gilbert and Jackaria (2002), and Mittal and Sethi (2011). The findings of the study infer that coupons are not effective at inducing brand switching behaviour. Free samples and BOGOF are equally likely to induce LIP purchase acceleration amongst African Generation $Y$ students, and discounts may also be appropriate in this regard. This is consistent with the findings of Gilbert and Jackaria (2002) who found that BOGOF and discount are effective for inducting purchase acceleration. Besides BOGOF and discount being effective at encouraging purchase acceleration, Shi et al. (2005) also found coupons being an effective technique, which is contradictory with the findings of this study. If the objective is to encourage stockpiling of LIPs, all four sales promotion techniques are suitable, with BOGOF and free samples being the most appropriate tools. This is consistent with the findings of Shi et al. (2005) but contradicting with the findings of Mittal and Sethi (2011) who found discount and coupon as effective techniques for encouraging stockpiling.

Free samples and, to a lesser degree, BOGOF promotions are important techniques for inducing LIP product trials amongst African Generation Y students which is consistent with the findings of Mittal and Sethi (2011), recommending BOGOF for inducing product trial, and Ndubisi and Moi (2006) and Kautish (2011), recommending free sample as an effective tool. Evidence from the sample suggests that coupons and discounts should be avoided when the objective is to induce the product trial of LIP. This is contradicting with the findings of Gilbert and Jackaria (2002), Ndubisi and Moi (2006) and Kautish (2011) recommending discount for encouraging product trial. Ndubisi and Moi (2006) and Kautish (2011) however concur with the findings of this study in that coupons are ineffective at encouraging product trial. Marketers of LIPs trying to develop brand loyalty amongst members of this cohort should consider using a combination of coupons, discounts, free samples and BOGOF promotions.

It is interesting to note that even though coupons do not hold the same appeal as the other sales promotion techniques amongst African Generation $Y$ students, coupons do appear to have value in the development of brand loyalty. The low appeal of coupons may be because students are relatively unfamiliar with this type of sales promotion technique. Alternatively, it may because collecting coupons requires effort and is time-consuming. Increasing the value of the coupons offered may act as a motivator and increase their effectiveness as a sales promotion technique.

\section{Conclusion}

Sales promotions are amongst the most effective techniques for influencing consumer buying behaviour and persuading consumers to purchase a specific product or brand in the FMCG sector. As such, it is essential that LIP retailers, manufacturers and marketers understand the preferred sales promotion techniques of different target markets. The findings of this study indicate that while African Generation $Y$ students in South Africa have an overall positive attitude towards the use of sales promotion techniques, they are particularly positive towards BOGOF promotions and free samples. Within this study, the focus was on students' attitudes towards sales promotion techniques specifically on LIPS and the opportunity exist to determine students' attitudes towards sales promotion techniques on HIPs. Furthermore, only four sales promotion techniques was the topic of interest in this study and was measured in isolation, allowing the opportunity to determine the attitudes towards other sales promotion techniques, such as rebates, scorecards or sweepstakes or to determine the interactions between the different techniques. Given that a quantitative research approach was followed in this study, the reasons for the attitudes towards the sales promotion techniques was not determined, future research in this area is recommended. 


\section{References}

Arens, W. F., Weigold, M. F., \& Arens, C. (2011). Contemporary advertising and integrated marketing communications. (13th ed.). New York: McGraw Hill.

Bala, M., \& Kumar, D. (2011). Supply chain performance attributes for the fast moving consumer goods industry. Journal of Transport and Supply Chain Management, 5(1), 23-38.

Belch, G. E., \& Belch, M. A. (2012). Advertising and promotion: an integrated marketing communication perspective. (9th ed.). New York: McGraw Hill.

Bevan-Dye, A. L., Dhurup, M., \& Surujlal, J. (2009). Black Generation Y students' perceptions of national sport celebrity endorsers as role models. African Journal for Physical, Health Education, recreation and dance:172-188.

Bird, S., Blem, N., Duckles, R., Koekemoer, L., Skinner, C., \& Van der Westuizen, B. (1998). Promotional strategy: marketing communications in practice. Kenwyn: Juta.

Clark, L. A., \& Watson, D. (1995). Construct validity: basic issues in objective scale development. Psychological Assessment, 7(3), 309319.

Dawes, J. (2004). Assessing the impact of a very successful price promotion on brand, category and competitor sales. Journal of Product and Brand Management, 13(5), 303-314.

Du Plessis, F., Cook, G., Van Heerden, N., Van Rooyen, R., Mulder, D., Du Plessis, L., Franck, A., \& Muir, C. (2010). Integrated marketing communication: a contemporary approach. (3rd ed.). Pretoria: Van Schaik.

Ferrell, O. C., \& Hartline, M. D. (2008). Marketing Strategy, (4th ed.). Mason: Thomson South-Western.

Field, A. (2009). Discovering statistics using SPSS. (3rd ed.). London: Sage.

Gamliel, E., \& Herstein, R. (2011). To save or to lose: does framing price promotion affect consumers' purchase intentions? Journal of Consumer Marketing, 28(2), 152-158.

Gardener, E., \& Trivedi, M. (1998). A communication framework to evaluate sale promotion strategies. Journal of Advertising Research, 38(3), 67-71.

Gilbert, D. C., \& Jackaria, N. (2002). The efficacy of sales promotions in UK supermarkets: a consumer view. International Journal of Retail and Distribution Management, 30(6), 315-322.

Hamlin, R. P., \& Wilson, T. (2004). The impact of cause branding on consumer reactions to products: does product/cause 'fit' really matter? Journal of Marketing Management, 20(7-8), 663-681.

HESA, (2009), Higher education in South Africa. [Online] Availible: http://www.southafricaweb.co.za/page/higher-education-south-africa (January 19, 2012)

Jensen, J. M., \& Hansen, T. (2006). An empirical examination of brand loyalty. Journal of Product and Brand Management, 15(7), 442449.

Kivetz, R., Urminsky, O., \& Zheng, Y. (2006). The goal-gradient hypotheses resurrected: purchase acceleration, illusionary goal progress, and customer retention. Journal of Marketing Research, 43(1), 39-58.

Kotler, P. (2003). Marketing management. (11th ed.). New Jersey: Prentice Hall.

Kristof, K. M. (2012). Feeding a family on \$300 a month. Kiplinger's Personal Finance, 66(3), 72-72.

Lamb, C. W., Hair, J. F., \& McDaniel, C. (2009). Essentials of marketing. (6th ed.). Mason: South-Western Cengage Learning.

Lamb, C. W., Hair, J. F., McDaniel, C., Boshoff, C., Terblanche, N., Elliott, R., \& Klopper, H. B. (2010). Marketing. (4th ed.). Cape Town: Oxford.

Leahy, R. (2011). Relationships in fast moving consumer goods markets: the consumers' perspective. European Journal of Marketing, 45(4), 651-672.

Markert, J. (2004). Demographics of age: generational and cohort confusion. Journal of Current Issues and Research in Advertising, 26(2), 11-25.

Mittal, M., \& Sethi, P. (2011). The effectiveness of sales promotion tools among Indian consumers: an imperial study. Journal of Promotion Management, 17(2), 165-182.

Moraga, E. T., Parraga, A. Z. V., \& González, J. Z. (2008). Customer satisfaction and loyalty: start with the product, culminate with the brand. Journal of Consumer Marketing, 25(5), 302-313.

Ndubisi, N. O., \& Moi, C. T. (2006). Awareness and usage of promotional tools by Malaysian consumers: the case of low involvement products. Management Research News, 29(1/2), 28-40.

Osman, S., Fah, B. C. Y., \& Foon, Y. S. (2011). Simulation of sales promotions towards buying behaviour among university students. International Journal of Marketing Studies, 3(3), 78-88.

Ouwersloot, H., \& Duncan, T. (2008). Integrated marketing communications. London: McGraw-Hill.

Percy, L. (2008). Strategic integrated marketing communications. Amsterdam: Butterworth-Heinemann.

Perreault, W. D., \& McCarthy, E. J. (2006). Essentials of marketing: a global managerial approach. (10th ed.). Boston: McGraw-Hill.

Pickton, D., \& Broderick, A. (2005). Integrated marketing communications. (2nd ed.). New York: Prentice Hall.

Pillay, P. (2007). The importance of branding fast moving consumer goods in retail chain stores: consumers and marketers perceptions in South Africa (Doctoral thesis). Retrieved from http://researchspace.ukzn.ac.za/xmlui

Pride, W. M., \& Ferrell, O. C. (2010). Marketing. (15th ed.). Mason: South-Western Cengage Learning.

Promotional Products Association International, (2004), Promotional products: impact, exposure and influence. [Online] Available: http://www.ppai.org/inside-ppai/research/Documents/PromotionalProducts- 
Impact\%20Exposure\%20and\%20Influence_SaleTool.pdf (January 20, 2012)

RMB Private Bank, (2011), The changing South African retail landscape. [Online] Available: https://www.rmbprivatebank.com/ downloads/RMBPrivateBank/evolve/service-approach/portfolioMangementView2011.pdf (January 21, 2012)

Schiffman, L. G., Kanuk, L. L., \& Wisenblit, J. (2010). Consumer behavior (10th ed.). New Jersey: Pearson Prentice Hall.

Semenik, R. J. (2002). Promotion and integrated marketing communications. Cincinnati: Thomson Learning.

Shi, Y. Z., Cheung, K. M., \& Prendergast, G. (2005). Behavioural response to sales promotion tools: a Hong Kong study. International Journal of Advertising, 24(4), 467-486.

Shimp, T. A. (2010). Advertising, promotion, and other aspects of integrated marketing communications. (8th ed.). Mason: SouthWestern Cengage Learning.

Shukla, P. (2009). Impact of contextual factors, brand loyalty and brand switching on purchase decisions. Journal of Consumer Marketing, 26(5), 348-357.

Statistics South Africa, (2011), Mid-year population estimates 2011: statistical release P0302. [Online] Available: http://www.statssa. gov.za (November 15, 2011)

Yeshin, T. (2006). Sales promotion. London: Thomson Learning. 
